\title{
TMPRSS2 and RNA-Dependent RNA Polymerase Are Effective Targets of Therapeutic Intervention for Treatment of COVID-19 Caused by SARS-CoV-2 Variants (B.1.1.7 and B.1.351)
}

\author{
Jihye Lee, ${ }^{a}$ JinAh Lee, ${ }^{a}$ Hyeon Ju Kim, ${ }^{\text {a }}$ Meehyun Ko, ${ }^{\text {a }}$ Youngmee Jee, ${ }^{b}$ Seungtaek Kim ${ }^{a}$ \\ aZoonotic Virus Laboratory, Institut Pasteur Korea, Seongnam, South Korea \\ ${ }^{b}$ CEO office, Institut Pasteur Korea, Seongnam, South Korea \\ JinAh Lee and Hyeon Ju Kim contributed equally to this article. Author order was determined in order of seniority.
}

ABSTRACT Severe acute respiratory syndrome coronavirus 2 (SARS-CoV-2) is a causative agent of the coronavirus disease 2019 (COVID-19) pandemic, and the development of therapeutic interventions is urgently needed. So far, monoclonal antibodies and drug repositioning are the main methods for drug development, and this effort was partially successful. Since the beginning of the COVID-19 pandemic, the emergence of SARS-CoV-2 variants has been reported in many parts of the world, and the main concern is whether the current vaccines and therapeutics are still effective against these variant viruses. Viral entry and viral RNA-dependent RNA polymerase (RdRp) are the main targets of current drug development; therefore, the inhibitory effects of transmembrane serine protease 2 (TMPRSS2) and RdRp inhibitors were compared among the early SARS-CoV-2 isolate (lineage A) and the two recent variants (lineage B.1.1.7 and lineage B.1.351) identified in the United Kingdom and South Africa, respectively. Our in vitro analysis of viral replication showed that the drugs targeting TMPRSS2 and RdRp are equally effective against the two variants of concern.

IMPORTANCE The COVID-19 pandemic is causing unprecedented global problems in both public health and human society. While some vaccines and monoclonal antibodies were successfully developed very quickly and are currently being used, numerous variants of the causative SARS-CoV-2 are emerging and threatening the efficacy of vaccines and monoclonal antibodies. In order to respond to this challenge, we assessed antiviral efficacy of small-molecule inhibitors that are being developed for treatment of COVID-19 and found that they are still very effective against the SARS-CoV-2 variants. Since most small-molecule inhibitors target viral or host factors other than the mutated sequence of the viral spike protein, they are expected to be potent control measures against the COVID-19 pandemic.

KEYWORDS COVID-19, RNA-dependent RNA polymerase, SARS-CoV-2, TMPRSS2, variant oronavirus disease 2019 (COVID-19) is an emerging infectious disease caused by a novel coronavirus, severe acute respiratory syndrome coronavirus 2 (SARS-CoV-2) (1), and it was declared as a pandemic by the WHO on March 11, 2020. To address this unprecedented global challenge, intensive investigations have been simultaneously conducted by global scientific communities and industries to develop diagnostic tools, vaccines, and therapeutics. Remarkably, within 10 months after release of the SARSCoV-2 genome sequence, a couple of vaccines were successfully developed and are now being used for vaccination of people after emergency use authorization (EUA). Drug development was also partially successful, especially in the development of monoclonal antibodies $(2,3)$. Notably, the vaccines and monoclonal antibodies currently being used are heavily

Citation Lee J, Lee J, Kim HJ, Ko M, Jee Y, Kim S. 2021. TMPRSS2 and RNA-dependent RNA polymerase are effective targets of therapeutic intervention for treatment of COVID-19 caused by SARS-CoV-2 variants (B.1.1.7 and B.1.351) Microbiol Spectr 9:e00472-21. https://doi.org/ 10.1128/Spectrum.00472-21.

Editor Cyprian C. Rossetto, University of Nevada, Reno

Copyright $\odot 2021$ Lee et al. This is an openaccess article distributed under the terms of the Creative Commons Attribution 4.0 International license. Address correspondence to Seungtaek Kim, seungtaek.kim@ip-korea.org.

Received 3 July 2021

Accepted 20 July 2021

Published 11 August 2021 


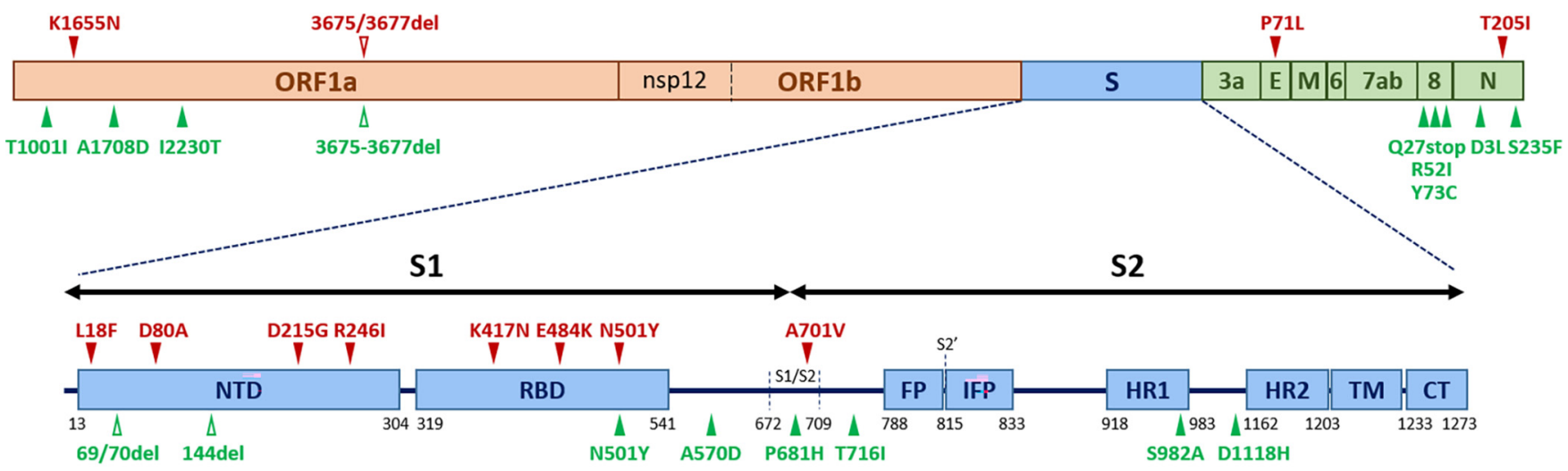

FIG 1 Schematic illustration of single-nucleotide polymorphisms (SNPs) in SARS-CoV-2 variants. Three SARS-CoV-2 lineages were used in this study: lineage A (an early SARS-CoV-2 isolate), lineage B.1.1.7 (identified in the United Kingdom), and lineage B.1.351 (identified in South Africa). SNPs that are observed in B.1.351 compared to the early isolate are noted in red above the diagram. SNPs observed in B.1.1.7 compared to the early isolate are noted in green below the diagram. NTD, N-terminal domain; RBD, receptor-binding domain; FP, fusion peptide; IFP, internal fusion peptide; HR1, heptad repeat 1; HR2, heptad repeat 2; TM, transmembrane anchor; $\mathrm{CT}$, cytoplasmic tail; ORF, open reading frame; del, deletion.

dependent on the structure and sequence of viral spike protein, which is a surface glycoprotein responsible for virus entry and interacts with the host receptor angiotensin-converting enzyme 2 (ACE2). Thus, if there is any mutation in this protein, it is likely to affect the efficacy of both vaccines and antibodies.

Since the beginning of the COVID-19 pandemic, variants of SARS-CoV-2 have been reported in many parts of the world, and the recent variants identified in the United Kingdom (lineage B.1.1.7), South Africa (lineage B.1.351), and Brazil (lineage P.1) are of particular concern due to multiple mutations in the spike gene (Fig. 1) $(4,5)$. Indeed, several results are being published that demonstrated reduced neutralization capacity of convalescent plasma, vaccine sera, and monoclonal antibodies against these variants (6-9).

In addition to monoclonal antibodies, small-molecule inhibitors are also being developed as potential antiviral agents. Targets of such small-molecule inhibitors are often transmembrane serine protease 2 (TMPRSS2) (10-13) and viral RNA-dependent RNA polymerase (RdRp) $(14,15)$. TMPRSS2 is known to possess serine protease activity, which primes the viral spike protein for fusion between the viral membrane and the host cell membrane before the release of viral genome into the cytoplasm. Camostat and nafamostat are representative drug candidates as TMPRSS2 inhibitors and are currently being tested in several phase 2 and 3 clinical trials in many countries (NCT04623021, NCT04390594, NCT04483960, NCT04521296, NCT04721535, NCT04530617, etc.). On the other hand, RdRp is a target of remdesivir, which is the first approved drug for treatment of COVID-19 patients (16).

In this study, we investigated whether the antiviral drug candidates targeting TMPRSS2 and RdRp are still effective against the recent SARS-CoV-2 variants of concern by assessing in vitro viral replication capacity after drug treatment.

\section{RESULTS AND DISCUSSION}

The alignment of SARS-CoV-2 amino acid sequences of two lineages (B.1.1.7 and B.1.351) identified numerous changes compared to the sequence of the early SARS-CoV-2 isolate (lineage A). Several changes were located in the spike protein (Fig. 1), while no change was observed in the NSP12 amino acid sequence, which possesses an RdRp activity.

In order to compare drug efficacy against the three lineages of SARS-CoV-2, both Vero cells (Table 1) and Calu-3 cells (Table 2 ) were used for virus infection and drug treatment. Drugs were added to the cells before virus infection. Cells were fixed at $24 \mathrm{~h}$ postinfection and scored by immunofluorescence analysis with an antibody specific for the viral nucleocapsid (N) protein. For all drugs, cytotoxicity results were identical among the three variants, having a $50 \%$ cytotoxic concentration $\left(\mathrm{CC}_{50}\right)$ value above the highest concentration tested $(5$ or $50 \mu \mathrm{M})$. The microscopic images of both viral $\mathrm{N}$ protein and cell nuclei were 
TABLE 1 Comparison of $\mathrm{IC}_{50}$ values among three SARS-CoV-2 variants in Vero cells

\begin{tabular}{|c|c|c|c|c|c|}
\hline Compound & $\frac{A}{\text { Mean } \pm S^{a}(\mu M)}$ & \multicolumn{2}{|l|}{ B.1.1.7 } & \multicolumn{2}{|l|}{ B.1.351 } \\
\hline Camostat & $>5$ & $>5$ & $\mathrm{NA}^{c}$ & $>5$ & NA \\
\hline Aprotinin & $>50$ & $>50$ & NA & $>50$ & NA \\
\hline Bromhexine & $20.31 \pm 0.420$ & $20.51 \pm 0.017$ & 0.526 & $20.70 \pm 0.253$ & 0.427 \\
\hline Niclosamide & $0.204 \pm 0.013$ & $0.192 \pm 0.007$ & 0.348 & $0.114 \pm 0.014$ & 0.022 \\
\hline Molnupiravir & $31.24 \pm 1.965$ & $>50$ & NA & $24.41 \pm 4.140$ & 0.219 \\
\hline EIDD-1931 & $1.699 \pm 0.126$ & $1.599 \pm 0.116$ & 0.557 & $1.336 \pm 0.122$ & 0.094 \\
\hline
\end{tabular}

${ }^{a}$ Mean of $50 \%$ inhibitory concentration $\left(\mathrm{IC}_{50}\right)$ values \pm standard deviation $(\mathrm{SD})$ of duplicate $\mathrm{IC}_{50}$ values.

${ }^{b}$ Student's $t$ test results by comparing $\mathrm{IC}_{50}$ values of $A$ to $I C_{50}$ values of B.1.1.7 or B.1.351.

'NA, not available.

analyzed using Columbus software, and the dose-response curve (DRC) for each drug and variant was generated (Fig. 2 and 3).

We tested four different TMPRSS2 inhibitors (camostat, nafamostat, aprotinin, and bromhexine) (17), two RdRp inhibitors (remdesivir, EIDD-2801 [molnupiravir], and EIDD-1931 [an active form of EIDD-2801]) $(14,15)$, and others (niclosamide and ciclesonide) that we had identified in our earlier drug repositioning study $(13,18)$. The antiviral drug efficacy of each drug was compared among the three lineages of SARS-CoV-2, A (an early SARS-CoV-2 isolate), B.1.1.7 (identified in the United Kingdom), and B.1.351 (identified in South Africa).

While TMPRSS2 inhibitors did not show any antiviral effect in Vero cells as reported previously (Fig. 2) (13), they were very effective in suppressing viral replication in Calu3 cells, perhaps due to the abundant TMPRSS2 expression in this cell line (19), without substantial differences in drug efficacy among the three lineages of SARS-CoV-2 (Fig. 3). TMPRSS2 cleaves the spike protein at the $S 2^{\prime}$ cleavage site, and no sequence change was observed at or near this site in the two recent variants (B.1.1.7 and B.1.351) compared to the sequence of the early SARS-CoV-2 isolate (lineage A) (Fig. 1). Perhaps, the conserved sequence at this region could account for the similar drug efficacy among the three lineages.

The amino acid sequence of NSP12 was also well conserved among the three lineages of SARS-CoV-2 (Fig. 1), and we did not find any substantial differences among them with regard to drug efficacy of the two representative RdRp inhibitors (remdesivir and molnupiravir) (Fig. 2 and 3). Both remdesivir and molnupiravir are nucleoside analogs; however, the two drugs differ from each other in that remdesivir works as a chain terminator but molnupiravir induces mutations during viral RNA replication. Molnupiravir (EIDD-2801) is a prodrug of $\beta$-D- $N^{4}$-hydroxycytidine (EIDD-1931), and it

TABLE 2 Comparison of $\mathrm{IC}_{50}$ values among three SARS-CoV-2 variants in Calu-3 cells

\begin{tabular}{|c|c|c|c|c|c|}
\hline Compound & $\frac{\mathrm{A}}{\text { Mean } \pm \mathrm{SD}^{a}(\mu \mathrm{M})}$ & \multicolumn{2}{|l|}{ B.1.1.7 } & \multicolumn{2}{|l|}{ B.1.351 } \\
\hline Camostat & $0.102 \pm 0.023$ & $0.108 \pm 0.006$ & 0.797 & $0.170 \pm 0.013$ & 0.064 \\
\hline Aprotinin & $0.696 \pm 0.333$ & $0.930 \pm 0.108$ & 0.457 & $1.037 \pm 0.364$ & 0.347 \\
\hline Bromhexine & $12.42 \pm 0.378$ & $12.20 \pm 0.392$ & 0.836 & $29.44 \pm 13.89$ & 0.285 \\
\hline Niclosamide & $1.587 \pm 0.119$ & $1.383 \pm 0.179$ & 0.475 & $1.210 \pm 0.021$ & 0.045 \\
\hline Molnupiravir & $1.979 \pm 0.161$ & $1.705 \pm 0.714$ & 0.916 & $3.403 \pm 0.030$ & 0.007 \\
\hline EIDD-1931 & $0.292 \pm 0.067$ & $0.245 \pm 0.014$ & 0.476 & $0.351 \pm 0.070$ & 0.355 \\
\hline
\end{tabular}

${ }^{a}$ Mean of $50 \%$ inhibitory concentration $\left(\mathrm{IC}_{50}\right)$ values \pm standard deviation $(\mathrm{SD})$ of duplicate $\mathrm{IC}_{50}$ values.

${ }^{b}$ Student's $t$ test results by comparing $I_{50}$ values of $A$ to $I C_{50}$ values of B.1.1.7 or B.1.351. 

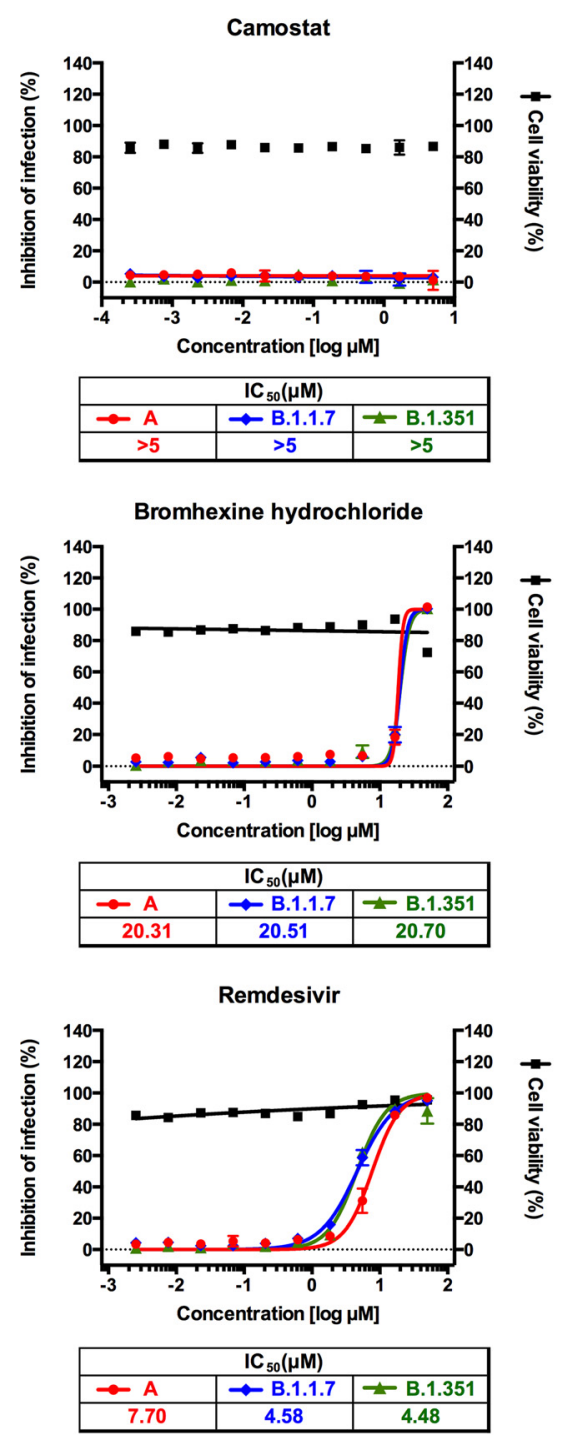
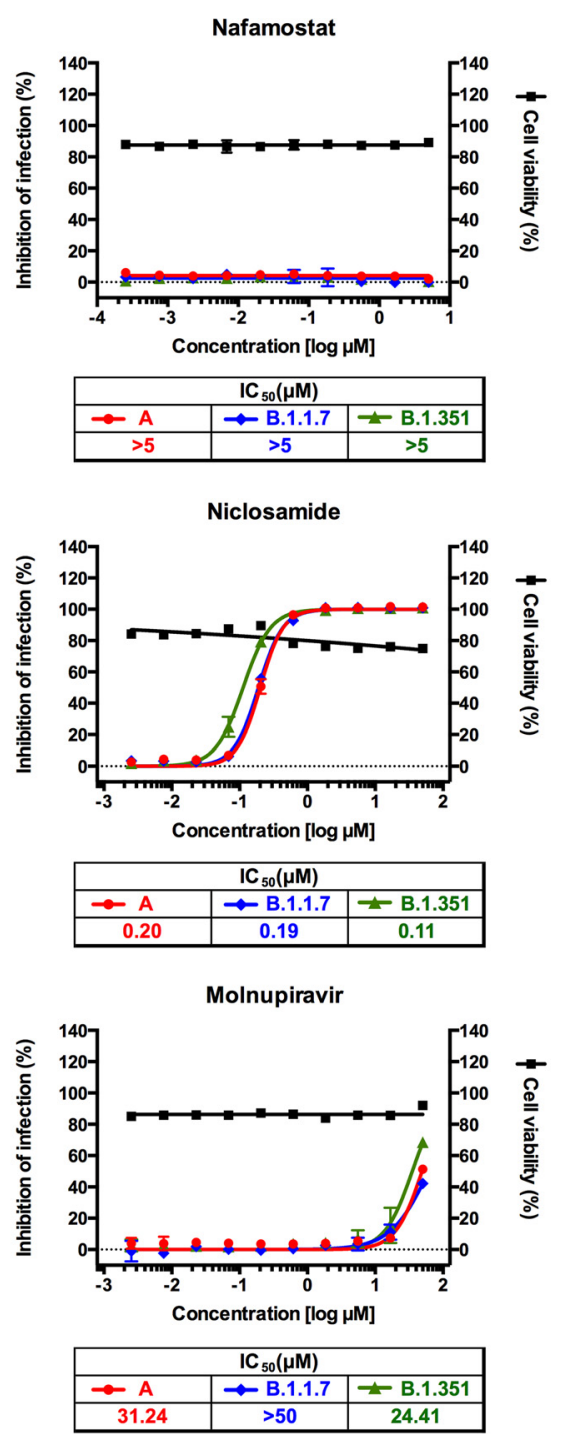
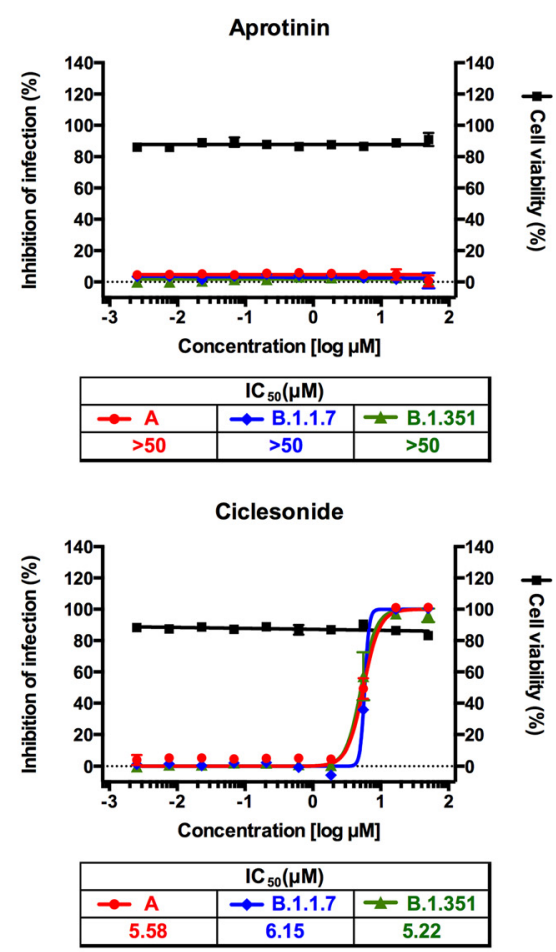

EIDD-1931

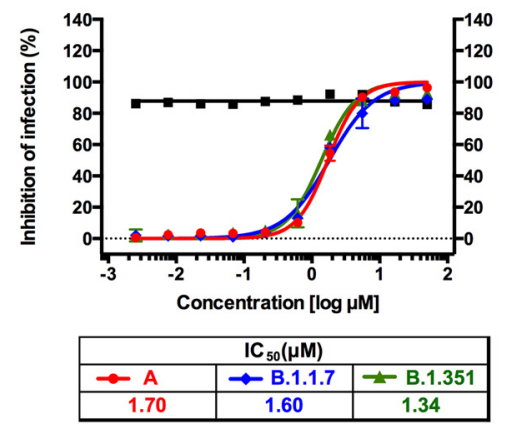

FIG 2 Dose-response curve analysis in Vero cells for the nine drugs that were tested in this study. The red circles (lineage A), blue diamonds (lineage B.1.1.7), and green triangles (lineage B.1.351) represent inhibition of SARS-CoV-2 infection (\%) in the presence of increasing concentrations of each drug, and the black squares represent cell viability (\%). In each panel, the symbols indicate actual data, while lines indicate the model fitting. Means \pm SD were calculated from duplicate experiments.

has well-known broad-spectrum antiviral activity against various RNA viruses (20-23). Since this drug is orally available, it could be easily administered for patients even with mild COVID-19 if it is successfully developed. Currently, phase 2 and 3 clinical trials are being conducted globally for this new drug candidate (NCT04405739, NCT04575597, NCT04939428, etc.).

Finally, we assessed the antiviral drug efficacy of niclosamide and ciclesonide, and no substantial differences in drug efficacy were observed among the three lineages (Fig. 2 and 3). This result suggests that the potential targets of these drugs lie outside the substituted amino acids in the two variants. Currently, niclosamide and ciclesonide are being tested in several clinical trials to assess antiviral efficacy against SARS-CoV-2 infection (NCT04330586, NCT04749173, NCT04399356, etc.).

Most monoclonal antibodies, convalescent plasma, and vaccines that are being used for treatment or prevention of COVID-19 were developed to target the viral spike protein, specifically, the receptor-binding domain. While this protein is abundant and more immunogenic than the other viral proteins, it is also the place where many mutations occur (e.g., N501Y, E484K, and K417N) due to potential viral adaptations and 
Camostat

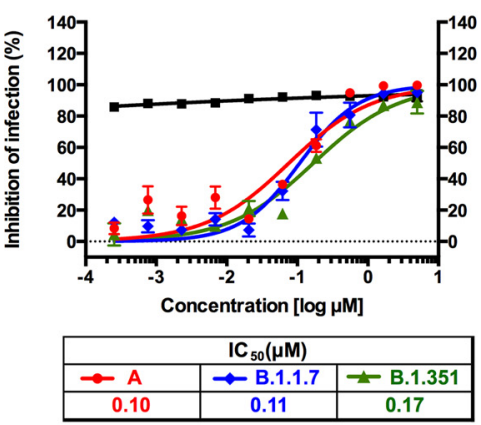

Bromhexine hydrochloride
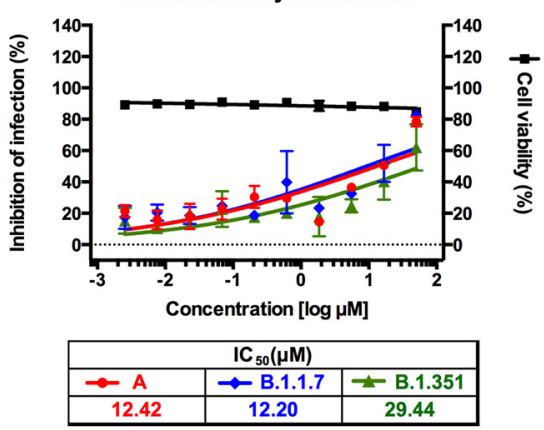

Remdesivir

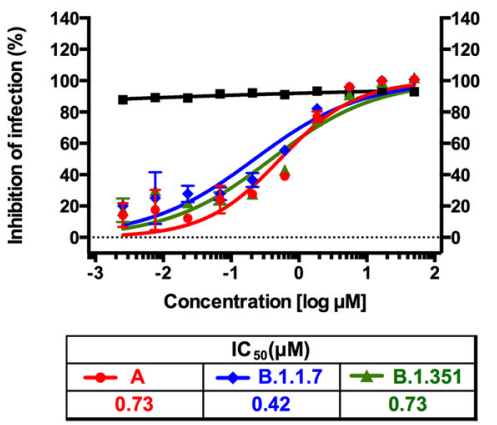

Nafamostat

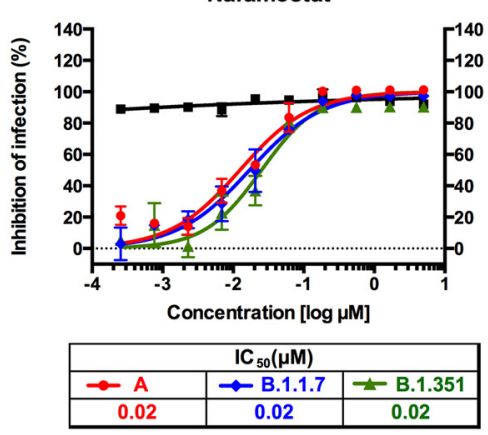

Niclosamide
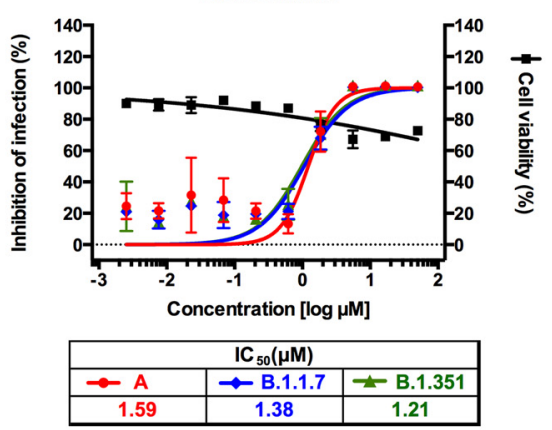

Molnupiravir
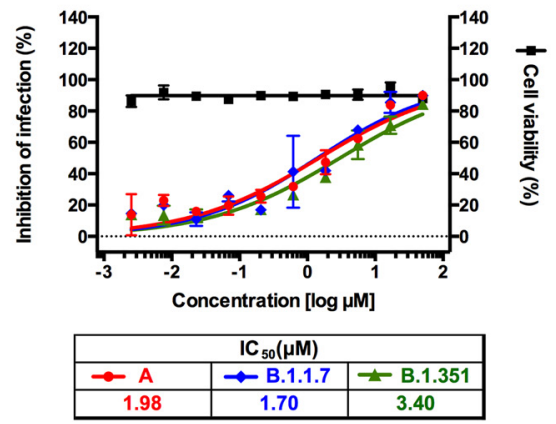

Aprotinin

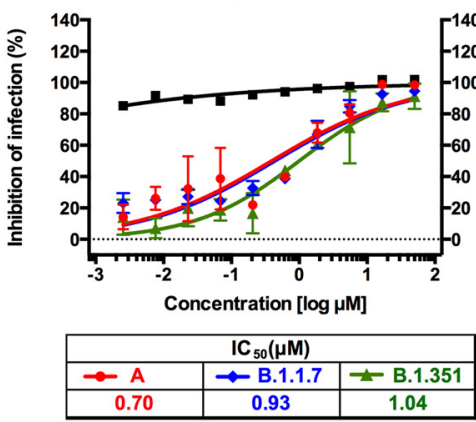

Ciclesonide

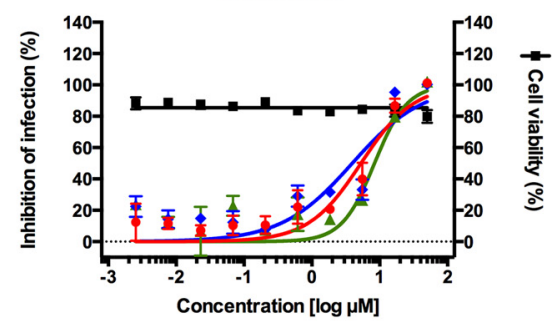

EIDD-1931
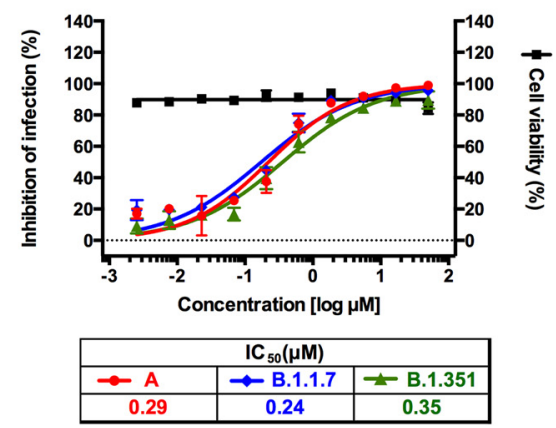

FIG 3 Dose-response curve analysis in Calu-3 cells for the nine drugs that were tested in this study. The red circles (lineage A), blue diamonds (lineage B.1.1.7), and green triangles (lineage B.1.351) represent inhibition of SARS-CoV-2 infection (\%) in the presence of increasing concentrations of each drug, and the black squares represent cell viability (\%). In each panel, the symbols indicate actual data, while lines indicate the model fitting. Means \pm SD were calculated from duplicate experiments.

various selective pressures, etc. Of these mutations, some are known to substantially reduce neutralization capacity of monoclonal antibodies, convalescent plasma, and vaccine sera. Hence, it is very important to develop therapeutics targeting viral or host factors other than the spike protein to address potential resistance issues caused by spike mutations.

In summary, we analyzed the efficacy of potential drug candidates (i.e., TMPRSS2 inhibitors, RdRp inhibitors, and others) against the recent SARS-CoV-2 variants of concern, and we found that all of them were equally effective in suppressing replication of B.1.1.7 and B.1.351 variants compared to the early SARS-CoV-2 isolate. The results from this study would help develop therapeutic interventions specifically targeting TMPRSS2, RdRp, or other viral and host factors.

\section{MATERIALS AND METHODS}

Virus and cells. Vero and Vero E6 cells were obtained from ATCC (CCL-81 and C1008, respectively) and maintained at $37^{\circ} \mathrm{C}$ with $5 \% \mathrm{CO}_{2}$ in Dulbecco's modified Eagle's medium (DMEM; Welgene) supplemented with $10 \%$ heat-inactivated fetal bovine serum (FBS) and $2 \%$ antibiotic-antimycotic solution (Gibco). The Calu-3 cell line used in this study is a clonal isolate, which shows a higher growth rate than 
the parental Calu-3 cell line obtained from ATCC (HTB-55). Calu-3 was maintained at $37^{\circ} \mathrm{C}$ with $5 \% \mathrm{CO}_{2}$ in Eagle's minimum essential medium (EMEM; ATCC) supplemented with $20 \%$ heat-inactivated FBS, $1 \%$ MEM-nonessential amino acid solution (Gibco), and 2\% antibiotic-antimycotic solution (Gibco). Three lineages of SARS-CoV-2 were provided by the Korea Disease Control and Prevention Agency (KDCA) and were propagated in Vero E6 cells. Each lineage is noted as lineage A (an early SARS-CoV-2 isolate) (hCoV-19/Korea/KCDC03/2020), lineage B.1.1.7 (hCoV-19/Korea/KDCA51463/2021), and lineage B.1.351 (hCoV-19/Korea/KDCA55905/2021) in this study. Viral titers were determined by plaque assays in Vero cells (24). All experiments using SARS-CoV-2 were performed at Institut Pasteur Korea in compliance with the guidelines of the Korea National Institute of Health $(\mathrm{KNIH})$ using enhanced biosafety level 3 (BSL-3) containment procedures in laboratories approved for use by the KDCA.

Reagents. All compounds except for ciclesonide and EIDD-1931 were purchased from MedChemExpress (Monmouth Junction, NJ, USA). Ciclesonide and EIDD-1931 were purchased from Cayman Chemical (Ann Arbor, MI, USA). The following are the lot numbers and purities of each compound: aprotinin (lot, 62009; purity of $\geq 98.0 \%$ ), bromhexine hydrochloride (lot, 15159; purity of $99.39 \%$ ), niclosamide (lot, 15718; purity of 98.68\%), ciclesonide (lot, 0472344-2; purity of $\geq 98.0 \%$ ), remdesivir (lot, 46182; purity of 99.78\%), EIDD-2801 (lot, 67548; purity of 99.94\%), and EIDD-1931 (lot, 0590872-1; purity of $\geq 95.0 \%$ ). Stock solution was dissolved in dimethyl sulfoxide (DMSO) at a $10 \mathrm{mM}$ concentration. Anti-SARS-CoV-2 N protein antibody was purchased from Sino Biological Inc. (Beijing, China). Alexa Fluor 488 goat anti-rabbit lgG (H $+\mathrm{L})$ secondary antibody and Hoechst 33342 were purchased from Molecular Probes. Paraformaldehyde (PFA) (32\% aqueous solution) and normal goat serum were purchased from Electron Microscopy Sciences (Hatfield, PA, USA) and Vector Laboratories, Inc. (Burlingame, CA, USA), respectively.

Dose-response curve analysis. Vero cells were seeded at $1.0 \times 10^{4}$ cells per well with DMEM (Welgene) supplemented with 2\% heat-inactivated FBS and $2 \%$ antibiotic-antimycotic solution (Gibco) in black, 384-well $\mu$ Clear plates (Greiner Bio-One) $24 \mathrm{~h}$ before the experiment. Calu-3 cells were seeded at $2.0 \times 10^{4}$ cells per well with EMEM (ATCC) supplemented with $20 \%$ heat-inactivated FBS, $1 \%$ MEM-nonessential amino acid solution (Gibco), and $2 \%$ antibiotic-antimycotic solution (Gibco) in black, 384-well $\mu$ Clear plates (Greiner Bio-One) $24 \mathrm{~h}$ before the experiment. The seeding density of Calu-3 cells was two times more than that for Vero cells due to the lower growth rate of Calu-3 cells. Ten-point DRCs were generated with 3-fold dilutions, with compound concentrations ranging from 0.0025 to $50 \mu \mathrm{M}$. Only nafamostat and camostat used a top concentration of $5 \mu \mathrm{M}$ instead of $50 \mu \mathrm{M}$; thus, concentrations ranged from 0.00025 to $5 \mu \mathrm{M}$. For viral infection, plates were transferred into the BSL-3 containment facility, and SARS-CoV-2 was added at a multiplicity of infection of 0.008 for Vero cells and 0.2 for Calu-3 cells. The plates were incubated at $37^{\circ} \mathrm{C}$ for $24 \mathrm{~h}$. The cells were fixed at $24 \mathrm{~h}$ postinfection with $4 \%$ PFA and permeabilized with $0.25 \%$ Triton X-100 solution. Anti-SARS-CoV-2 nucleocapsid (N) primary antibody, 488-conjugated goat anti-rabbit lgG secondary antibody, and Hoechst 33342 were applied to the cells for immunofluorescence. Images acquired with an Operetta high-throughput imaging device (PerkinElmer) were analyzed using Columbus software (PerkinElmer) to quantify cell numbers and infection ratios. Antiviral activity was normalized to infection control (0.5\% DMSO) in each assay plate. Cell viability was measured by counting nuclei in each well and normalizing it to the mock control. The plots for DRCs were generated using Prism7 software (GraphPad, San Diego, CA, USA). The 50\% inhibitory concentration $\left(\mathrm{IC}_{50}\right)$ and $50 \%$ cytotoxic concentration $\left(\mathrm{CC}_{50}\right)$ values were calculated using nonlinear regression analysis, log(inhibitor concentration) versus response - variable slope (four parameters) with the following equation: $Y=$ bottom $+($ top - bottom $) /\left(1+10^{[(\log \mid C 50-X) \times \text { Hillslope }]}\right)$. All IC $C_{50}$ and $C_{50}$ values were measured in duplicate.

\section{ACKNOWLEDGMENTS}

The pathogen resources (NCCP43326, NCCP43381, and NCCP43382) for this study were provided by the National Culture Collection for Pathogens. This work was supported by the National Research Foundation of Korea (NRF) grant funded by the Korean government (MSIT) (NRF-2017M3A9G6068245, NRF-2020M3E9A1041756, and NRF-2020M3A9I2081692).

\section{REFERENCES}

1. Zhou P, Yang X-L, Wang X-G, Hu B, Zhang L, Zhang W, Si H-R, Zhu Y, Li B, Huang C-L, Chen H-D, Chen J, Luo Y, Guo H, Jiang R-D, Liu M-Q, Chen Y, Shen X-R, Wang X, Zheng X-S, Zhao K, Chen Q-J, Deng F, Liu L-L, Yan B, Zhan F-X, Wang Y-Y, Xiao G-F, Shi Z-L. 2020. A pneumonia outbreak associated with a new coronavirus of probable bat origin. Nature 579: 270-273. https://doi.org/10.1038/s41586-020-2012-7.

2. Chen P, Nirula A, Heller B, Gottlieb RL, Boscia J, Morris J, Huhn G, Cardona J, Mocherla B, Stosor V, Shawa I, Adams AC, Van Naarden J, Custer KL, Shen L, Durante M, Oakley G, Schade AE, Sabo J, Patel DR, Klekotka P, Skovronsky DM, BLAZE-1 Investigators. 2021. SARS-CoV-2 neutralizing antibody LY-CoV555 in outpatients with Covid-19. N Engl J Med 384: 229-237. https://doi.org/10.1056/NEJMoa2029849.

3. Weinreich DM, Sivapalasingam S, Norton T, Ali S, Gao H, Bhore R, Musser BJ, Soo Y, Rofail D, Im J, Perry C, Pan C, Hosain R, Mahmood A, Davis JD, Turner KC, Hooper AT, Hamilton JD, Baum A, Kyratsous CA, Kim Y, Cook A, Kampman W, Kohli A, Sachdeva Y, Graber X, Kowal B,
DiCioccio T, Stahl N, Lipsich L, Braunstein N, Herman G, Yancopoulos GD, Trial Investigators. 2021. REGN-COV2, a neutralizing antibody cocktail, in outpatients with Covid-19. N Engl J Med 384:238-251. https://doi.org/10.1056/NEJMoa2035002.

4. Fontanet A, Autran B, Lina B, Kieny MP, Karim SSA, Sridhar D. 2021. SARSCoV-2 variants and ending the COVID-19 pandemic. Lancet 397:952-954. https://doi.org/10.1016/S0140-6736(21)00370-6.

5. Mascola JR, Graham BS, Fauci AS. 2021. SARS-CoV-2 viral variants-tackling a moving target. JAMA 325:1261-1262. https://doi.org/10.1001/jama .2021.2088.

6. Greaney AJ, Loes AN, Crawford KHD, Starr TN, Malone KD, Chu HY, Bloom JD. 2021. Comprehensive mapping of mutations in the SARS-CoV-2 receptor-binding domain that affect recognition by polyclonal human plasma antibodies. Cell Host Microbe 29:463-476. https://doi.org/10.1016/j.chom.2021.02.003.

7. Liu Z, VanBlargan LA, Bloyet L-M, Rothlauf PW, Chen RE, Stumpf S, Zhao $\mathrm{H}$, Errico JM, Theel ES, Liebeskind MJ, Alford B, Buchser WJ, Ellebedy AH, 
Fremont DH, Diamond MS, Whelan SPJ. 2021. Identification of SARS-CoV2 spike mutations that attenuate monoclonal and serum antibody neutralization. Cell Host Microbe 29:477-488. https://doi.org/10.1016/j.chom .2021.01.014.

8. Thomson EC, Rosen LE, Shepherd JG, Spreafico R, da Silva Filipe A, Wojcechowskyj JA, Davis C, Piccoli L, Pascall DJ, Dillen J, Lytras S, Czudnochowski N, Shah R, Meury M, Jesudason N, De Marco A, Li K, Bassi J, O'Toole A, Pinto D, Colquhoun RM, Culap K, Jackson B, Zatta F, Rambaut A, Jaconi S, Sreenu VB, Nix J, Zhang I, Jarrett RF, Glass WG, Beltramello M, Nomikou K, Pizzuto M, Tong L, Cameroni E, Croll TI, Johnson N, Di lulio J, Wickenhagen A, Ceschi A, Harbison AM, Mair D, Ferrari P, Smollett K, Sallusto F, Carmichael S, Garzoni C, Nichols J, Galli M, et al. 2021. Circulating SARS-CoV-2 spike N439K variants maintain fitness while evading antibody-mediated immunity. Cell 184:1171-1187. https://doi.org/10.1016/j .cell.2021.01.037.

9. Wang Z, Schmidt F, Weisblum Y, Muecksch F, Barnes CO, Finkin S, Schaefer-Babajew D, Cipolla M, Gaebler C, Lieberman JA, Oliveira TY, Yang Z, Abernathy ME, Huey-Tubman KE, Hurley A, Turroja M, West KA, Gordon K, Millard KG, Ramos V, Da Silva J, Xu J, Colbert RA, Patel R, Dizon J, Unson-O'Brien C, Shimeliovich I, Gazumyan A, Caskey M, Bjorkman PJ, Casellas R, Hatziioannou T, Bieniasz PD, Nussenzweig MC. 2021. mRNA vaccine-elicited antibodies to SARS-CoV-2 and circulating variants. Nature 592:616-617. https://doi.org/10.1038/s41586-021-03324-6.

10. Hoffmann M, Kleine-Weber H, Schroeder S, Krüger N, Herrler T, Erichsen $S$, Schiergens TS, Herrler G, Wu N-H, Nitsche A, Müller MA, Drosten C, Pöhlmann S. 2020. SARS-CoV-2 cell entry depends on ACE2 and TMPRSS2 and is blocked by a clinically proven protease inhibitor. Cell 181:271-280. https://doi.org/10.1016/j.cell.2020.02.052.

11. Hoffmann M, Schroeder S, Kleine-Weber $H$, Müller MA, Drosten C, Pöhlmann S. 2020. Nafamostat mesylate blocks activation of SARS-CoV-2: new treatment option for COVID-19. Antimicrob Agents Chemother 64: e00754-20. https://doi.org/10.1128/AAC.00754-20.

12. Yamamoto $M$, Kiso $M$, Sakai-Tagawa $Y$, Iwatsuki-Horimoto $K$, Imai $M$, Takeda M, Kinoshita N, Ohmagari N, Gohda J, Semba K, Matsuda Z, Kawaguchi Y, Kawaoka Y, Inoue J. 2020. The anticoagulant nafamostat potently inhibits SARS-CoV-2 S protein-mediated fusion in a cell fusion assay system and viral infection in vitro in a cell-type-dependent manner. Viruses 12:629. https://doi.org/10.3390/v12060629.

13. Ko M, Jeon S, Ryu W, Kim S. 2021. Comparative analysis of antiviral efficacy of FDA-approved drugs against SARS-CoV-2 in human lung cells. J Med Virol 93:1403-1408. https://doi.org/10.1002/jmv.26397.

14. Sheahan TP, Sims AC, Graham RL, Menachery VD, Gralinski LE, Case JB, Leist SR, Pyrc K, Feng JY, Trantcheva I, Bannister R, Park Y, Babusis D, Clarke MO, Mackman RL, Spahn JE, Palmiotti CA, Siegel D, Ray AS, Cihlar T, Jordan R, Denison MR, Baric RS. 2017. Broad-spectrum antiviral GS5734 inhibits both epidemic and zoonotic coronaviruses. Sci Transl Med 9:eaal3653. https://doi.org/10.1126/scitranslmed.aal3653.

15. Sheahan TP, Sims AC, Zhou S, Graham RL, Pruijssers AJ, Agostini ML, Leist SR, Schäfer A, Dinnon KH, Stevens LJ, Chappell JD, Lu X, Hughes TM, George AS, Hill CS, Montgomery SA, Brown AJ, Bluemling GR, Natchus
MG, Saindane M, Kolykhalov AA, Painter G, Harcourt J, Tamin A, Thornburg NJ, Swanstrom R, Denison MR, Baric RS. 2020. An orally bioavailable broad-spectrum antiviral inhibits SARS-CoV-2 in human airway epithelial cell cultures and multiple coronaviruses in mice. Sci Transl Med 12:eabb5883. https://doi.org/10.1126/scitranslmed.abb5883.

16. Beigel JH, Tomashek KM, Dodd LE, Mehta AK, Zingman BS, Kalil AC, Hohmann E, Chu HY, Luetkemeyer A, Kline S, Lopez de Castilla D, Finberg RW, Dierberg K, Tapson V, Hsieh L, Patterson TF, Paredes R, Sweeney DA, Short WR, Touloumi G, Lye DC, Ohmagari N, Oh M, Ruiz-Palacios GM, Benfield T, Fätkenheuer G, Kortepeter MG, Atmar RL, Creech CB, Lundgren J, Babiker AG, Pett S, Neaton JD, Burgess TH, Bonnett T, Green M, Makowski M, Osinusi A, Nayak S, Lane HC, ACT-1 Study Group Members. 2020. Remdesivir for the treatment of Covid-19_-final report. N Engl J Med 383:1813-1826. https://doi.org/10.1056/NEJMoa2007764.

17. Shen LW, Mao HJ, Wu YL, Tanaka Y, Zhang W. 2017. TMPRSS2: a potential target for treatment of influenza virus and coronavirus infections. Biochimie 142:1-10. https://doi.org/10.1016/j.biochi.2017.07.016.

18. Jeon S, Ko M, Lee J, Choi I, Byun SY, Park S, Shum D, Kim S. 2020. Identification of antiviral drug candidates against SARS-CoV-2 from FDAapproved drugs. Antimicrob Agents Chemother 64:e00819-20. https://doi .org/10.1128/AAC.00819-20.

19. Murgolo N, Therien AG, Howell B, Klein D, Koeplinger K, Lieberman LA, Adam GC, Flynn J, McKenna P, Swaminathan G, Hazuda DJ, Olsen DB. 2021. SARS-CoV-2 tropism, entry, replication, and propagation: considerations for drug discovery and development. PLoS Pathog 17:e1009225. https://doi.org/10.1371/journal.ppat.1009225.

20. Reynard O, Nguyen X-N, Alazard-Dany N, Barateau V, Cimarelli A, Volchkov V. 2015. Identification of a new ribonucleoside inhibitor of Ebola virus replication. Viruses 7:6233-6240. https://doi.org/10.3390/v7122934.

21. Urakova N, Kuznetsova V, Crossman DK, Sokratian A, Guthrie DB, Kolykhalov AA, Lockwood MA, Natchus MG, Crowley MR, Painter GR, Frolova El, Frolov I. 2018. $\beta$-D- $N^{4}$-Hydroxycytidine is a potent anti-alphavirus compound that induces a high level of mutations in the viral genome. J Virol 92:e01965-17. https://doi.org/10.1128/JVI.01965-17.

22. Toots M, Yoon JJ, Cox RM, Hart M, Sticher ZM, Makhsous N, Plesker R, Barrena AH, Reddy PG, Mitchell DG, Shean RC, Bluemling GR, Kolykhalov AA, Greninger AL, Natchus MG, Painter GR, Plemper RK. 2019. Characterization of orally efficacious influenza drug with high resistance barrier in ferrets and human airway epithelia. Sci Transl Med 11:eaax5866. https:// doi.org/10.1126/scitranslmed.aax5866.

23. Agostini ML, Pruijssers AJ, Chappell JD, Gribble J, Lu X, Andres EL, Bluemling GR, Lockwood MA, Sheahan TP, Sims AC, Natchus MG, Saindane M, Kolykhalov AA, Painter GR, Baric RS, Denison MR. 2019. Small-molecule antiviral $\beta$-D- $N^{4}$-hydroxycytidine inhibits a proofreadingintact coronavirus with a high genetic barrier to resistance. J Virol 93: e01348-19. https://doi.org/10.1128/JVI.01348-19.

24. Mendoza EJ, Manguiat K, Wood H, Drebot M. 2020. Two detailed plaque assay protocols for the quantification of infectious SARS-CoV-2. Curr Protoc Microbiol 57:ecpmc105. https://doi.org/10.1002/cpmc.105. 